Reseña

\section{Victoria Basualdo, Hartmut Berghoff and Marcelo Bucheli. Big Business and Dictatorships in Latin America: A Transnational History of Profits and Repression. London, Palgrave Macmillan, 2020, 408 pp. ISBN: 978-3030439248.}

Anyone familiar with the modern history of Latin America is aware of the immense influence that large corporations like the United Fruit Company or ITT have exerted in the continent. In the late 1960s and 1970s, their raw power provoked widespread denunciation of foreign firms as agents of imperialism and even inspired great literature by the likes of Pablo Neruda, Eduardo Galeano and Gabriel García Márquez. In that same period, Latin American intellectuals developed dependency theory to account for continued global economic inequalities despite efforts to industrialize and modernize local economies. However, academic interest in the role of capital declined in subsequent decades, in part because widespread human rights violations committed by military dictatorships became a top concern, and in part because of an intellectual turn toward subaltern and cultural studies.

This ambitious new edited volume both attests to, and aims to foster, a revival of academic attention to the role played by business elites in Latin America. Specifically, it examines the actions undertaken by private corporations and business leaders during the authoritarian military regimes of the cold war era. Latin American societies are still contending with the legacies of that violent period, not only in the realms of human rights and transitional justice, but also in economic and social terms. Most of those dictatorships (with the notable exception of Peru) aggressively dismantled the import substitution industrialization model that had shaped policy since the 1930s, driving down real wages, deepening social inequality, and intensifying the concentration of capital. Thirty years after the end of the cold war, Big Business and Dictatorships brings together scholars from Latin America, North America, and Europe to revisit that period and investigate to what extent private corporations collaborated with, and benefited from, those military regimes.

The ideas that inform this work were first incubated in a workshop setting, which lends the volume greater cohesion than many edited collections. Even though the individual chapters employ diverse methodologies, they all engage with a common set of empirical questions about the relationships between business elites, democratic governments, and military regimes. They examine to what extent corporations participated in the overthrow of democratic institutions, map out the personal and professional relationships that linked business elites to military governments, and evaluate how economic and labor policies undertaken by authoritarian regimes may have forwarded the interests of large corporations, both national and multinational. They also inquire into the impact of those policies on workers and labor unions, and they examine the extent of corporate collusion with, or at least passive acceptance of, massive human rights abuses committed under military rule.

The book is divided into fourteen chapters. Editors Victoria Basualdo, Hartmut Berghoff, and Marcelo Bucheli, historians who hail from Argentina, Germany, and Colombia respectively, use the opening chapter to situate the volume within the existing historiography and define its major contributions. They begin by synthesizing the ample literature on business collaboration with the Nazi regime, noting where it might provide guidance to Latin American researchers in this new field. They also note how Big Business moves beyond an exclusive focus on U.S. capital to include attention to German, Canadian, Italian, and Latin American corporations as well. Finally, they situate this work within a body of recent studies that put political economy and labor at the center of cold war scholarship, challenging purely political and diplomatic interpretations.

The other thirteen chapters analyze specific countries and regions. The Southern Cone countries of Argentina, Brazil, Chile, and Uruguay together account for the bulk of the volume, though Colombia and Peru are also represented. As the editors themselves note, Mexico is a significant omission. However, to be fair, the "perfect dictatorship" of single-party rule by the Partido Revolucionario Institucionalizado (PRI) makes Mexico something of an outlier in a collection focused on business relationships with overt military regimes. Also missing are Paraguay, Venezuela, Bolivia, the Dominican Republic, and Haiti, and the fourteenth chapter about Central America chapter reads as more of a brisk overview than an in-depth case study. However, these limitations do not detract from the contributions of this already substantial volume.

One of the book's great achievements is its interdisciplinary approach. Its eighteen contributors, who hail from several Latin American countries as well as Germany and the United States, draw on expertise from political economy, business history, law, economic and social history, sociology, political science, and international relations. They tackle the volume's guiding questions using different methodologies, such as company-specific case studies, network analyses, or reviews of policy impacts. This large-scale collaboration builds bridges across several disciplinary divides, for example by putting business history approaches into dialogue with those derived from labor history or political economy, or by addressing responsibility for human rights violations by tracking international financial flows.

The book's strength also derives from its fine-grained empirical analysis. Rather than start from a particular theoretical 
model, each author takes an open-ended approach that leaves room for contradictory and messy evidence. For example, several chapters show that private corporations did not always get what they wanted from authoritarian governments. Dictators who sought to shore up their own power sometimes pushed powerful corporations, including multinationals, to accept policies that curbed their autonomy. For instance, Volkswagen do Brasil had to submit to continued heavy regulation under the military regime that held power from 1964 to 1985 . Even banana giant United Brands had to pay higher royalties when the governments of Central America created the Banana Export Countries Union in 1974.

However, that same empirical rigor lends even greater power to the damning evidence presented in this volume regarding the scale of business complicity with authoritarian governments. In the most extreme cases, corporations like Ford Motors Argentina S. A. provided blacklists of labor organizers to security forces, who abducted workers straight from the assembly line and tortured them on the grounds of the facility. International commercial banks also undermined multilateral efforts to hold dictatorships accountable for human rights violations by sustaining them with massive loans when govern- ments and international agencies withheld funding. Several chapters document the close personal relationships that linked business elites to military regimes and point to a revolving door pattern of employment that saw generals appointed to corporate boards and business leaders appointed to key government positions. These close collaborations boosted the power of corporations and economic groups that came to dominate national economies after the transition to democracy. As several authors demonstrate, both national and international business elites expressed indifference to human rights crimes so long as their investments were safe.

This ambitious and timely collection promises to inspire new collaborations and new research into the cold war era in Latin America. It should be required reading for scholars, lawyers, and activists who continue to grapple with the legacies of that period.

Karen Robert

St. Thomas University

https://doi.org/10.33231/j.ihe.2022.01.007 